\title{
ナノコンポジット絶縁材料のアドバンテージとポテンシャル
}

1. はじめに

ポリマーナノコンポジットは，ポリマーにナノメーター スケールの無機フィラー（ナノ粒子）を少量添加した材料 で, 元の材料と比較して, 絶縁性能等を飛躍的に向上でき ることが大きな魅力である。

世界的な関心の高まりの中で, 先端複合ポリマーナノコ ンポジット誘電体の応用技術調査専門委員会では, これま でに技術報告第 1051 号(1)及び第 1148 号(2)を上梓し，誘電 絶縁材料としてのポリマーナノコンポジット（ナノコンポ ジット絶縁材料）に関する基礎特性と適用可能な応用分野 を報告している。ここでは，技術報告を基に，ナノコンポ ジット絶縁材料の概要を，そのアドバンテージ（優位性） とポテンシャル（可能性）をキーワードにして紹介する。

\section{2. ナノコンポジット絶縁材料のアドバンテージ}

ナノコンポジット絶縁材料に用いられるナノ粒子として は，シリカ $\left(\mathrm{SiO}_{2}\right)$ ，アルミナ $\left(\mathrm{Al}_{2} \mathrm{O}_{3}, \mathrm{AlOOH}\right)$, 酸化チ タン $\left(\mathrm{TiO}_{2}\right)$, クレイ (層状粘土鉱物) など挙げられる。ま た，ナノ粒子のポリマーへの均一分散（ナノコンポジット

化）が，誘電・絶縁特性に与える影響を鳥瞰すると表 1 の ようになる(1)。

例えば，ナノコンポジット絶縁材料では，耐部分放電性 が劇的に改善されることが報告されている。図 1 に示すよ

表 1 ナノコンポジット化が誘電・絶縁特性に与える影響(1)

\begin{tabular}{|c|c|c|}
\hline \multirow{2}{*}{ 材料特性 } & \multicolumn{2}{|c|}{ 実験結果 } \\
\hline & 傾向 & ベースポリマー \\
\hline 誘電率 & 減少する場合がある & PA, EP \\
\hline 誘電正接 $(\tan \delta)$ & 商用周波数で減少 & $\mathrm{EP}, \mathrm{PI}$ \\
\hline \multirow{2}{*}{ 低電界導電率 } & 増加 & PP, EVA \\
\hline & 減少 & EP \\
\hline 高電界導電率 & しきい值·電流が減少 & $P P, E V A$ \\
\hline 高電界空間電荷 & しきい値·電荷が減少 & $\mathrm{PP}, \mathrm{EVA}, \mathrm{EP}, \mathrm{PE}$ \\
\hline 熱刺激電流 & ピークが高温側にシフト & $\mathrm{EP}, \mathrm{PI}$ \\
\hline エレクトロルミネセンス & しきい値·応答速度が増大 & EP \\
\hline 絶縁破壊強度 & 増大 & PP, EVA, EP, PI \\
\hline 電気卜リ-破壊寿命 & 増大 & EP \\
\hline 耐部分放電性 & 増大 & PA, EP, PI, SR, PEI \\
\hline 耐トラッギグ 性 & 増大 & SR \\
\hline 自由体積 & 増大 & EP \\
\hline キャリヤートラップ & 増大 & PP, EVA, EP \\
\hline
\end{tabular}

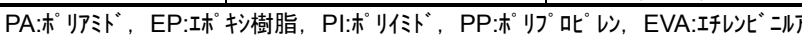

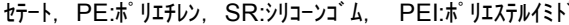

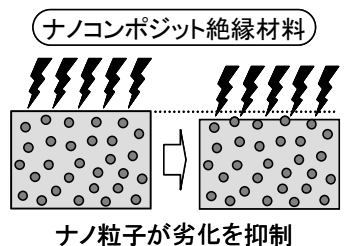

ポリマー(ナノ粒子無し)
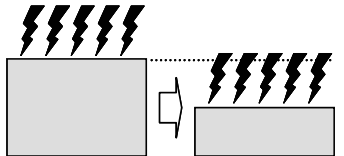

部分放電により劣化

うに，ナノコンポジット絶縁材料では，放電に対して高い 耐性をもつナノ粒子が，ポリマーを保護するため，放電に よる劣化が抑制される。このように，耐部分放電性の増大 など, 絶縁材料にとって必須の特性を, ナノ粒子の少量添 加で向上できることがナノコンポジット絶縁材料のアドバ ンテージである。

3. 電カ・社会インフラ分野におけるナノコンポジット 絶縁材料のポテンシャル

送変電機器やケーブル, 回転電機や電動機, 或いはキャ パシタなどでは，環境調和と省エネルギーを目的として， 高電圧大容量化, 小型化, 高効率化が進められており, 従 来絶縁材料よりも優れた特性を持つ材料の開発が期待され ている。ナノコンポジット絶縁材料は，これらの要求を満 たすポテンシャル持つ材料の一つである。

ナノコンポジット絶縁材料が適用可能な分野を図 2 に示 す。送変電機器（絶縁スペーサ・固体絶縁スイッチギヤ）, 直流高電圧押出ケーブル，マグネットワイヤ，キャパシタ， 回転電機 (インバータ駆動モーター), 全固体変電所, 屋外 絶縁機器（ポリマー碍子）などを挙げることができる(2)。

耐インバータサージ性マグネットワイヤ（PEI ナノコン ポジット）のように既に実用化され上市されているもの， 直流高電圧押出ケーブル（PEナノコンポジット）のように 実用化の一歩手前のもの, 基礎研究段階であるものなど, その研究開発の進渉は様々であるが，ナノコンポジット絶 縁材料の広範な分野における実用化は，これからの研究開 発次第であると言える。

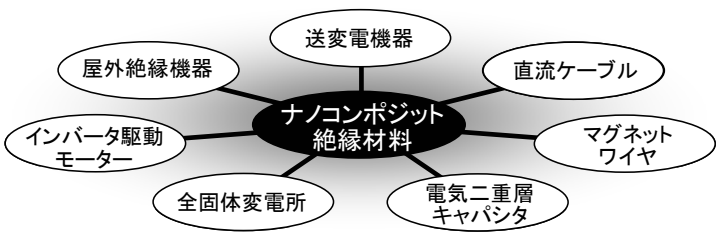

図 2 ナノコンポジット絶縁材料が応用可能な分野

\section{文献}

（1）電気学会 ナノコンポジット材料の誘電・絶縁応用技術調査専門委員 会 :「ポリマーナノコンポジット材料の誘電・絶縁技術応用」, 電気 学会技術報告, No.1051, p.4 (2006)

(2) 電気学会 ナノコンポジット誘電体の界面現象と応用技術調查専門 委員会:「革新的なポリマーナノコンポジットの性質と電気絶縁への 応用」，電気学会技術報告，No.1148, p.72 (2009)

先端複合ポリマーナノコンポジット誘電体の応用技術 調查専門委員会

図 1 ナノコンポジット絶縁材料の耐部分放電性

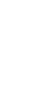

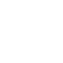

